\title{
Calcium dynamics in bovine adrenal medulla chromaffin cell secretory granules
}

\author{
Jaime SantoDomingo, Laura Vay, Marcial Camacho, ${ }^{*}$ Esther Hernández-SanMiguel, Rosalba I. Fonteriz, \\ Carmen D. Lobatón, Mayte Montero, Alfredo Moreno and Javier Alvarez \\ Instituto de Biología y Genética Molecular (IBGM), Departamento de Bioquímica y Biología Molecular y Fisiología, Facultad de \\ Medicina, Universidad de Valladolid and Consejo Superior de Investigaciones Científicas (CSIC), Ramón y Cajal, 7, E-47005 \\ Valladolid, Spain
}

Keywords: aequorin, $\mathrm{Ca}^{2+}$, chromaffin, inositol 1,4,5-trisphosphate, secretory granules

\begin{abstract}
The secretory granules constitute one of the less well-known compartments in terms of $\mathrm{Ca}^{2+}$ dynamics. They contain large amounts of total $\mathrm{Ca}^{2+}$, but the free intragranular $\left[\mathrm{Ca}^{2+}\right]\left(\left[\mathrm{Ca}^{2+}\right] \mathrm{sG}\right)$, the mechanisms for $\mathrm{Ca}^{2+}$ uptake and release from the granules and their physiological significance regarding exocytosis are still matters of debate. We used in the present work an aequorin chimera targeted to the granules to investigate $\left[\mathrm{Ca}^{2+}\right]_{S G}$ homeostasis in bovine adrenal chromaffin cells. We found that most of the intracellular aequorin chimera is present in a compartment with $50-100 \mu \mathrm{M} \mathrm{Ca}^{2+} . \mathrm{Ca}^{2+}$ accumulation into this compartment takes place mainly through an ATP-dependent mechanism, namely, a thapsigargin-sensitive $\mathrm{Ca}^{2+}$-ATPase. In addition, fast $\mathrm{Ca}^{2+}$ release was observed in permeabilized cells after addition of inositol 1,4,5-trisphosphate $\left(\operatorname{Ins}_{3}\right)$ or caffeine, suggesting the presence of $\operatorname{Ins} \mathrm{P}_{3}$ and ryanodine receptors in the vesicular membrane. Stimulation of intact cells with the Ins $\mathrm{P}_{3}$-producing agonist histamine or with caffeine also induced $\mathrm{Ca}^{2+}$ release from the vesicles, whereas acetylcholine or high- $\left[\mathrm{K}^{+}\right]$depolarization induced biphasic changes in vesicular $\left[\mathrm{Ca}^{2+}\right]$, suggesting heterogeneous responses of different vesicle populations, some of them releasing and some taking up $\mathrm{Ca}^{2+}$ during stimulation. In conclusion, our data show that chromaffin cell secretory granules have the machinery required for rapid uptake and release of $\mathrm{Ca}^{2+}$, and this strongly supports the hypothesis that granular $\mathrm{Ca}^{2+}$ may contribute to its own secretion.
\end{abstract}

\section{Introduction}

The increase in intracellular $\left[\mathrm{Ca}^{2+}\right]$ triggers exocytosis of secretory vesicles in neuronal and neuroendocrine cells. The $\mathrm{Ca}^{2+}$ required for exocytosis usually enters from the extracellular medium through several kinds of plasma membrane $\mathrm{Ca}^{2+}$ channels (Garcia et al., 2006). In addition, exocytosis may also be induced by the release of $\mathrm{Ca}^{2+}$ from intracellular $\mathrm{Ca}^{2+}$ stores, mainly the endoplasmic reticulum (ER), through either inositol trisphosphate $\left(\mathrm{InsP}_{3}\right)$ receptors or ryanodine receptors (RyRs). In fact, $\mathrm{Ca}^{2+}$ entry may activate $\mathrm{Ca}^{2+}$ release from the ER through RyRs, thus potentiating exocytosis. This phenomenon, known as $\mathrm{Ca}^{2+}$-induced $\mathrm{Ca}^{2+}$ release, has been shown to be operative in chromaffin cells (Alonso et al., 1999). However, it is hardly mentioned that the main $\mathrm{Ca}^{2+}$ store in some excitable cells resides in the secretory vesicles. In chromaffin cells, secretory granules contain about $60 \%$ of the total cellular $\mathrm{Ca}^{2+}$ (Haigh et al., 1989), and the total $\mathrm{Ca}^{2+}$ concentration inside the granules has been estimated to be around $40 \mathrm{~mm}$ (Winkler \& Westhead, 1980; Hutton, 1989). The reason for

Correspondence: Dr J. Alvarez, as above.

E-mail: jalvarez@ibgm.uva.es

*Present address: Departamento de Medicina Física y Farmacología, Facultad de Medicina, Universidad de La Laguna, E-38071 Tenerife, Spain.

Received 28 April 2008, revised 28 July 2008, accepted 5 August 2008 this apparent oversight is that whereas the importance of $\mathrm{Ca}^{2+}$ dynamics in organelles such as the ER or mitochondria is now fully established (Rizzuto et al., 2004), the physiological significance of the $\mathrm{Ca}^{2+}$ stored in secretory granules is still obscure.

An attractive possibility would be that intragranular $\mathrm{Ca}^{2+}$ could contribute to its own secretion by being released through $\mathrm{Ca}^{2+}$ channels situated in the granule membrane. In fact, it has been claimed that $\mathrm{InsP}_{3}$ may release $\mathrm{Ca}^{2+}$ from chromaffin granules (Yoo \& Albanesi, 1991), and the same authors recently described the presence of $\mathrm{InsP}_{3}$ receptors in the secretory granule membrane (Huh et al., 2005). Similarly, the presence of $\operatorname{Ins}_{3}$ receptors has been reported in mast cell secretory granules (Quesada et al., 2001, 2003) and in pancreatic acinar cell secretory granules (Gerasimenko et al., 1996, 2006). However, results from other authors indicate that in chromaffin cells, $\mathrm{Ins}_{3}$ receptors are present in the ER but not in the secretory granules (Endo et al., 2006). Moreover, it was shown in PC12 cells that both the agonist-induced and the high- $\left[\mathrm{K}^{+}\right]$-induced $\left[\mathrm{Ca}^{2+}\right]$ increases are identical in the cytosol and in the outer side of the granule membrane, suggesting that there is little $\mathrm{Ca}^{2+}$ release from the granules during stimulation (Pouli et al., 1998).

We have investigated here the dynamics of intragranular $\left[\mathrm{Ca}^{2+}\right]$ in primary cultures of bovine adrenal medulla chromaffin cells by using an adenoviral vector to express a vesicle-associated membrane protein 
(VAMP)-aequorin chimera targeted to the membrane of the secretory vesicles. This chimera was used for the first time to monitor intragranular $\left[\mathrm{Ca}^{2+}\right]$ in MIN6 $\beta$-cells (Mitchell et al., 2001, 2003), showing secretory granule $\left[\mathrm{Ca}^{2+}\right]\left(\left[\mathrm{Ca}^{2+}\right]_{\mathrm{SG}}\right)$ values around $50 \mu \mathrm{M}$, and is the same that we have used before to study granule $\left[\mathrm{Ca}^{2+}\right]$ dynamics in PC12 cells (Moreno et al., 2005). However, we have now used a higher- $\mathrm{Ca}^{2+}$-affinity form of that aequorin chimera, which we have found is much superior for monitoring the free $\left[\mathrm{Ca}^{2+}\right]_{\mathrm{SG}}$, and provides a considerable amount of new information on its dynamics.

\section{Materials and methods}

\section{Cell culture and expression of aequorin and enhanced green fluorescent protein (EGFP) chimeras}

Bovine adrenal glands were kindly provided by the veterinary of the slaughterhouse Justino Gutiérrez of Laguna de Duero (Valladolid, Spain). The study was approved by the ethical committee of animal experimentation of the Faculty of Medicine of the University of Valladolid. Bovine adrenal medulla chromaffin cells were isolated as described previously (Moro et al., 1990) and plated on 12-mm glass polylysine-coated coverslips $\left(0.25 \times 10^{6}\right.$ cells per $1 \mathrm{~mL}$ of Dulbecco's modified Eagle's medium). Cells were cultured in high-glucose $(4.5 \mathrm{~g} / \mathrm{L})$ Dulbecco's modified Eagle's medium supplemented with $10 \%$ fetal bovine serum, 50 i.u. $\mathrm{mL}^{-1}$ penicillin and 50 i.u. $\mathrm{mL}^{-1}$ streptomycin. Cultures were maintained at $37^{\circ} \mathrm{C}$ in a humidified atmosphere of $5 \% \mathrm{CO}_{2}$.

The vesicle-associated membrane protein-mutated aequorin (VAMPmutaeq) chimera has been described previously (Mitchell et al., 2001; Moreno et al., 2005). The VAMP-EGFP construct was made by inserting in frame the VAMP sequence in the HindIII site of the pEGFPN1 plasmid. For construction of adenoviral vectors, full-length cDNA encoding these constructs was subcloned into the pShuttle vector and then used for construction of the corresponding adenoviral vector by using an AdenoX adenovirus construction kit (Clontech).

Chromaffin cells were infected with adenoviruses for expression of the constructs described above. Infection was carried out on the day after cell isolation, and $\left[\mathrm{Ca}^{2+}\right]$ measurements were performed $48-72 \mathrm{~h}$ after infection. Efficiency of infection of chromaffin cells with the adenovirus carrying the VAMP-EGFP chimera was estimated to be about $60 \%$.

\section{$\left[\mathrm{Ca}^{2+}\right]_{S G}$ measurements with aequorin}

Cells were plated onto $12-\mathrm{mm}$ polylysine-covered round coverslips and infected with adenoviruses to express VAMP-mutaeq. For aequorin reconstitution in intact cells (non- $\mathrm{Ca}^{2+}$-depleted), cells expressing VAMP-mutaeq were incubated for $1-2 \mathrm{~h}$ at room temperature with either $1 \mu \mathrm{M}$ native coelenterazine or $1 \mu \mathrm{M}$ coelenterazine $\mathrm{n}$, in standard medium (145 mM NaCl, $5 \mathrm{mM} \mathrm{KCl}, 1 \mathrm{mM} \mathrm{MgCl}_{2}, 1 \mathrm{mM}$ $\mathrm{CaCl}_{2}, 10 \mathrm{~mm}$ glucose, and $10 \mathrm{~mm}$ Hepes, $\mathrm{pH}$ 7.4). For experiments with $\mathrm{Ca}^{2+}$-depleted cells, cells were treated for $10 \mathrm{~min}$ with the ionophores ionomycin $(10 \mu \mathrm{M})$ and monensin $(10 \mu \mathrm{M})$ and the sarcoendoplasmic reticulum $\mathrm{Ca}^{2+}$-ATPase (SERCA) inhibitor $t$-butyl benzohydroquinone (BHQ, $10 \mu \mathrm{M}$ ) in $\mathrm{Ca}^{2+}$-free standard medium (containing $0.5 \mathrm{mM}$ EGTA instead of $\mathrm{Ca}^{2+}$ ). Then, cells were incubated for $1-2 \mathrm{~h}$ in the same $\mathrm{Ca}^{2+}$-free extracellular medium without the ionophores, but containing BHQ and $1 \mu \mathrm{M}$ native coelenterazine. Cells were then placed in the perfusion chamber of a purpose-built thermostatized luminometer. The temperature was $37^{\circ} \mathrm{C}$ for the experiments using colenterazine $\mathrm{n}$ (Fig. 2) and $22^{\circ} \mathrm{C}$ for all the other experiments, performed using native colenterazine. We have shown before that this temperature change produces a small shift in the $\mathrm{Ca}^{2+}$ affinity of the aequorin, allowing monitoring of relatively high $\left[\mathrm{Ca}^{2+}\right]$ values for a longer time (Barrero et al., 1997). For experiments with permeabilized cells, cells expressing VAMP-mutaeq were reconstituted with coelenterazine for $1-2 \mathrm{~h}$ and then placed in the luminometer as indicated above in standard medium containing $0.5 \mathrm{~mm}$ EGTA instead of $\mathrm{Ca}^{2+}$. Then, a 5-min pulse with $500 \mu \mathrm{M}$ lanthanum was given, followed again by standard medium containing $0.5 \mathrm{mM}$ EGTA for $3 \mathrm{~min}$, prior to permeabilization for $1 \mathrm{~min}$ with $20 \mu \mathrm{M}$ digitonin in intracellular medium $(130 \mathrm{mM} \mathrm{KCl}, 10 \mathrm{mM} \mathrm{NaCl}$, $1 \mathrm{~mm} \mathrm{MgCl}_{2}, 1 \mathrm{~mm} \mathrm{~K}_{3} \mathrm{PO}_{4}, 0.5 \mathrm{~mm}$ EGTA, $1 \mathrm{~mm}$ ATP, $20 \mu \mathrm{M}$ ADP, $2 \mathrm{mM}$ succinate, $20 \mathrm{~mm}$ HEPES, $\mathrm{pH}$ 7). Then, intracellular medium without digitonin and containing $100 \mathrm{nM} \mathrm{Ca}^{2+}$ (prepared with an EGTA/ $\mathrm{Ca}^{2+}$ mixture) was finally perfused to refill the vesicular $\mathrm{Ca}^{2+}$ store. Calibration of the luminescence data into $\left[\mathrm{Ca}^{2+}\right]$ was performed using an algorithm as previously described (Alvarez \& Montero, 2002). Calibration requires release of all the aequorin luminescence present in the cells at the end of every experiment. In intact cells, this is done by perfusing a water solution containing $20 \mu \mathrm{M}$ digitonin and $10 \mathrm{mM} \mathrm{Ca}^{2+}$. In previously permeabilized cells, a $10 \mathrm{mM} \mathrm{Ca} \mathrm{Ca}^{2+}$ solution is perfused at the end of the experiments.

\section{Calibration of mutated aequorin at $\mathrm{pH} 7$ and $\mathrm{pH} 5.5$}

Comparison of the luminescence obtained from mutated aequorin at either $\mathrm{pH} 7$ or 5.5 was performed using HeLa cells expressing mutated aequorin targeted to the ER. HeLa cells were cultured and transfected with the ER-targeted mutated aequorin construct as described previously (Montero et al., 1997a). The ER was irreversibly depleted of $\mathrm{Ca}^{2+}$ by incubation with $1 \mu \mathrm{M}$ thapsigargin during reconstitution with $1 \mu \mathrm{M}$ native coelenterazine. Cells were also incubated during reconstitution with $5 \mu \mathrm{M}$ oligomycin, to avoid mitochondrial ATP production. Then, cells were placed in the luminometer, permeabilized as described above (except for the use of a higher digitonin concentration, $100 \mu \mathrm{M}$ ), and perfused with intracellular medium containing no ATP and no metabolic substrates, the ionophores ionomycin $(1 \mu \mathrm{M})$ and carbonyl cyanide 4-(trifluoromethoxy)phenylhydrazone (FCCP) $(2 \mu \mathrm{M})$, and the SERCA pump inhibitor BHQ. In this way, the ER becomes unable to accumulate $\mathrm{Ca}^{2+}$ and behaves simply as an aequorin container, freely permeable to $\mathrm{Ca}^{2+}$ and $\mathrm{H}^{+}$, and ready for the performance of a calibration in the desired conditions. Cells were then perfused under these conditions with different $\mathrm{Ca}^{2+}$ concentrations, from 5 to $200 \mu \mathrm{M}$, and using intracellular medium at either $\mathrm{pH} 7$ (buffered with HEPES) or $\mathrm{pH} 5.5$ (buffered with citrate).

\section{Secretory granule $\mathrm{pH}$ measurements with VAMP-EGFP}

Cells were plated onto $12-\mathrm{mm}$ polylysine-covered round coverslips and infected with adenoviruses to express VAMP-EGFP. Forty-eight hours after infection, cells were mounted in a cell chamber in the stage of a Zeiss Axiovert 200 microscope under continuous perfusion. Single-cell fluorescence was excited at $480 \mathrm{~nm}$ using a Cairn monochromator (200 ms excitation every $2 \mathrm{~s}, 10-\mathrm{nm}$ bandwidth), and images of the emitted fluorescence obtained with a $40 \times$ Fluar objective were collected using a 495DCLP dichroic mirror and an E515LPV2 emission filter (both from Chroma Technology) and recorded with a Hamamatsu ORCA-ER camera. Single-cell fluorescence records were analyzed using the METAfluOR program (Universal Imaging Corporation, Downingtown, PA, USA). Experiments were performed at $22^{\circ} \mathrm{C}$. 


\section{Confocal measurements}

Chromaffin cells expressing VAMP-EGFP were imaged on a Leica TCS SP2 confocal spectrophotometer using a $63 \times$ oil immersion objective. EGFP was excited with the 488-nm line of the argon laser, and the fluorescence emitted between 500 and $600 \mathrm{~nm}$ was collected. Images were then deconvoluted using HUYGENS software (Scientific Volume Imaging, Hilversum, The Netherlands).

\section{Materials}

Wild-type coelenterazine and coelenterazine $\mathrm{n}$ were obtained from Molecular Probes (OR, USA). Bafilomycin A was from Tocris (Bristol, UK). InsP $P_{3}$, cADP-ribose (cADPR), nicotinic acid adenine dinucleotide phosphate (NAADP) and FCCP were from Sigma (Madrid, Spain). Other reagents were from Sigma or Merck (Darmstadt, Germany). Statistical data are always given in mean \pm SEM, and the number is indicated in each case. The ANOVA test was used to study the significance of the differences. To estimate the differences, the pre-stimulus $\left[\mathrm{Ca}^{2+}\right]$ was measured immediately before the addition of the stimulus.

\section{Results}

\section{Subcellular distribution of VAMP-mutaeq in chromaffin cells}

The subcellular distribution of VAMP-mutaeq in chromaffin cells was explored in two ways. First, we prepared an adenovirus able to express a construct containing EGFP instead of aequorin attached to VAMP. When we infected chromaffin cells with that virus and obtained confocal fluorescence images of cells expressing VAMP-EGFP, the

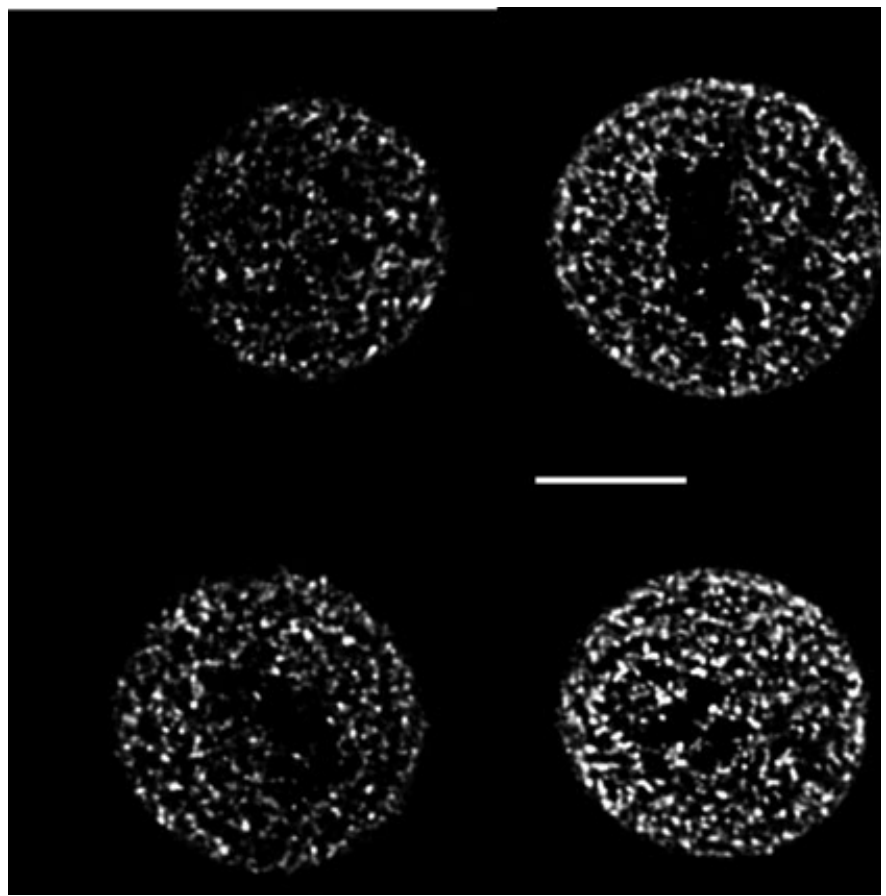

FIG. 1. Confocal fluorescence images of vesicle-associated membrane protein (VAMP)-enhanced green fluorescent protein (EGFP) in bovine chromaffin cells. Chromaffin cells were infected with adenovirus carrying the VAMPEGFP construct, and confocal microscopy was performed $48 \mathrm{~h}$ later, as described in Materials and methods. The figure shows fluorescence images with a typical granular pattern obtained in four different confocal planes of a single labeled cell. Scale bar: $5 \mu \mathrm{m}$. resulting images clearly showed a granular distribution (Fig. 1). This is consistent with previous results showing that this chimera colocalizes almost exclusively with secretory granules in chromaffin cells (Allersma et al., 2004).

Both the images shown in Fig. 1 and previous results provide evidence that VAMP-EGFP, and thus probably also VAMP-mutaeq, is well targeted to the chromaffin granules. In addition, the good specificity of targeting of the VAMP-mutaeq chimera to secretory vesicles has been previously shown by immunofluorescence and immunoelectron microscopy in insulin-containing secretory vesicles of MIN6 $\beta$-cells (Mitchell et al., 2001), where less than 3\% of the probe was shown to be in the ER or Golgi compartments. On the other hand, functional evidence for the targeting of this aequorin chimera to the granules can also be provided by using the properties of aequorin luminescence, in particular the irreversible light emission from aequorin induced by $\mathrm{Ca}^{2+}$, the so-called aequorin consumption.

First, we found that reconstitution of intact chromaffin cells expressing VAMP-mutaeq with native coelenterazine produced hardly any functional photoprotein (data not shown). In contrast, when we used coelenterazine $\mathrm{n}$ to reconstitute mutaeq, we obtained exponentially decreasing records of aequorin luminescence like that shown in Fig. 2a. These results show that mutaeq is present in compartments with $\left[\mathrm{Ca}^{2+}\right]$ high enough both to preclude reconstitution with native coelenterazine and to produce a fast initial rate of consumption when reconstituted with coelenterazine $\mathrm{n}$. The kind of record shown in Fig. 2a was very similar to those found before in PC12 cells (Moreno et al., 2005). When this luminescence record was transformed into

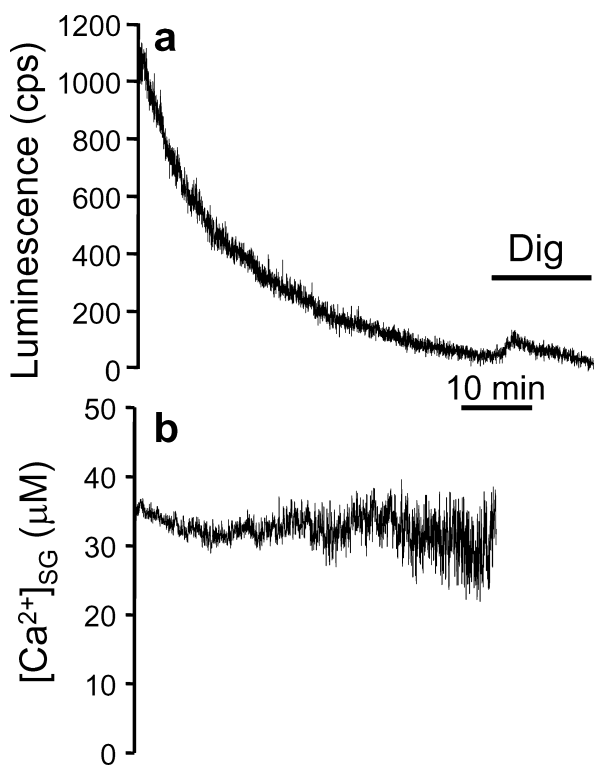

FIG. 2. Steady-state $\left[\mathrm{Ca}^{2+}\right]$ in chromaffin secretory granules $\left(\left[\mathrm{Ca}^{2+}\right]_{\mathrm{SG}}\right)$ measured with low- $\mathrm{Ca}^{2+}$-affinity vesicle-associated membrane protein (VAMP)mutated aequorin chimera (VAMP-mutaeq) in non- $\mathrm{Ca}^{2+}$-depleted cells. Bovine chromaffin cells expressing VAMP-mutaeq were reconstituted with coelenterazine $\mathrm{n}$ (see Materials and methods), and luminescence was then monitored under continuous perfusion with external medium containing $1 \mathrm{mM} \mathrm{Ca}^{2+}(\mathrm{cps}$, counts per second). (a) Crude luminescence record, which decreases exponentially due to aequorin consumption at the high intragranular $\left[\mathrm{Ca}^{2+}\right]$. When indicated, standard medium containing $20 \mu \mathrm{M}$ digitonin and $10 \mathrm{mM} \mathrm{Ca}^{2+}$ (Dig) was perfused, showing that little residual luminescence was left. (b) The calibrated $\left[\mathrm{Ca}^{2+}\right]$ values obtained from the same experiment, showing a stable steady-state $\left[\mathrm{Ca}^{2+}\right]$ around $35 \mu \mathrm{M}$. This experiment was performed at $37^{\circ} \mathrm{C}$, and is representative of 45 similar ones. 
$\left[\mathrm{Ca}^{2+}\right]$ values (Fig. 2b), we obtained a steady-state $\left[\mathrm{Ca}^{2+}\right]$ of $30 \pm 1 \mu \mathrm{M}$ (mean $\pm \mathrm{SEM}, n=45$ ). Addition of digitonin and high $\left[\mathrm{Ca}^{2+}\right]$ at the end of the experiment produced only a very small release of luminescence, showing that nearly all of the reconstituted aequorin molecules had already been consumed. This confirms the absence of significant amounts of reconstituted aequorin in lower- $\left[\mathrm{Ca}^{2+}\right]$ compartments.

\section{The problem of the resting $\left[\mathrm{Ca}^{2+}\right]$ in the secretory granules}

The conclusion from these experiments is that functional VAMPmutaeq is present mainly in one compartment with a homogeneous $\left[\mathrm{Ca}^{2+}\right]$ around $30 \mu \mathrm{M}$. However, this $\left[\mathrm{Ca}^{2+}\right]$ value is in the lower limit of the $\left[\mathrm{Ca}^{2+}\right]$ range detected by this aequorin chimera (mutaeq reconstituted with coelenterazine $\mathrm{n}$ ), and thus it should have very little sensitivity to $\left[\mathrm{Ca}^{2+}\right]$ changes, particularly to $\mathrm{Ca}^{2+}$ release from the granules. In fact, we have used this probe before to monitor $\left[\mathrm{Ca}^{2+}\right]$ in the ER, which is around $500 \mu \mathrm{M}$ (Montero et al., 1997a; Alonso et al., 1999). Thus, a probe with higher $\mathrm{Ca}^{2+}$ sensitivity would be better for studying the dynamics of $\left[\mathrm{Ca}^{2+}\right]_{\mathrm{SG}}$. However, as we have mentioned above, the resting $\left[\mathrm{Ca}^{2+}\right]_{\mathrm{SG}}$ did not allow reconstitution when an aequorin with higher $\mathrm{Ca}^{2+}$ affinity, such as mutaeq reconstituted with native coelenterazine, was used. Then, we decided to deplete the granules of $\mathrm{Ca}^{2+}$ prior to reconstitution, using the ionophores monensin and ionomycin (see Materials and methods). Cells were then reconstituted with native coelenterazine in the absence of extracellular $\mathrm{Ca}^{2+}$, and readdition of $\mathrm{Ca}^{2+}$ triggered a large luminescence peak (Fig. 3a). When calibrated into $\left[\mathrm{Ca}^{2+}\right]$ values (Fig. 3b), the peak rose to above $100 \mu \mathrm{M}$. Then, after the peak, $\left[\mathrm{Ca}^{2+}\right]$ dropped rapidly and showed a prolonged shoulder starting at about $30 \mu \mathrm{M}\left[\mathrm{Ca}^{2+}\right]$.

The presence of both a peak and a shoulder suggests that aequorin is situated in at least two different compartments, one of them reaching a much higher $\left[\mathrm{Ca}^{2+}\right]$ than the other. Among the possible compartments where VAMP-mutaeq could be, it is quite obvious that some VAMPmutaeq could have reached the plasma membrane following the secretory pathway. In that case, fusion of the vesicles with the plasma membrane would lead to exposure of the VAMP-linked aequorin to the extracellular medium, so that it would be rapidly burnt after the addition of extracellular $\mathrm{Ca}^{2+}$. In fact, the confocal images of VAMPEGFP always show a certain amount of the fluorescence in the plasma membrane. In intact (non- $\mathrm{Ca}^{2+}$-depleted) cells, those VAMP-mutaeq molecules could never be reconstituted, because of the high extracellular $\left[\mathrm{Ca}^{2+}\right]$. Instead, in $\mathrm{Ca}^{2+}$-depleted cells, reconstitution is possible, as the extracellular medium is devoid of $\mathrm{Ca}^{2+}$. To distinguish between intracellular VAMP-mutaeq and that present in the plasma membrane, we gave a brief pulse containing lanthanum in order to trigger specifically the luminescence from aequorin present on the extracellular side of the plasma membrane (Shimomura \& Johnson, 1973). Lanthanum is known to be unable to enter chromaffin cells (Marley et al., 2000), and its effects on plasma membrane channels or transporters should be rapidly reversible after washout with EGTAcontaining medium. The experiment shown in Fig. 3c demonstrates that perfusion of lanthanum generated, in fact, a peak of luminescence. Then, once lanthanum had consumed all the plasma membrane VAMPmutaeq luminescence, it was washed out for $5 \mathrm{~min}$ and the subsequent addition of $\mathrm{Ca}^{2+}$ triggered a much smaller peak of luminescence, corresponding only to intracellular aequorin. After translation into $\left[\mathrm{Ca}^{2+}\right]$ values (Fig. 3d), we obtained a peak of around $40 \mu \mathrm{M}$ (41 $\pm 2 \mu \mathrm{M}, n=80$ ), followed by a prolonged and slowly decreasing shoulder with $\left[\mathrm{Ca}^{2+}\right]$ values of $17.2 \pm 0.5 \mu \mathrm{M}(n=80) 5 \mathrm{~min}$ after the peak and $14.8 \pm 0.4 \mu \mathrm{M}(n=80) 10 \mathrm{~min}$ after the peak.
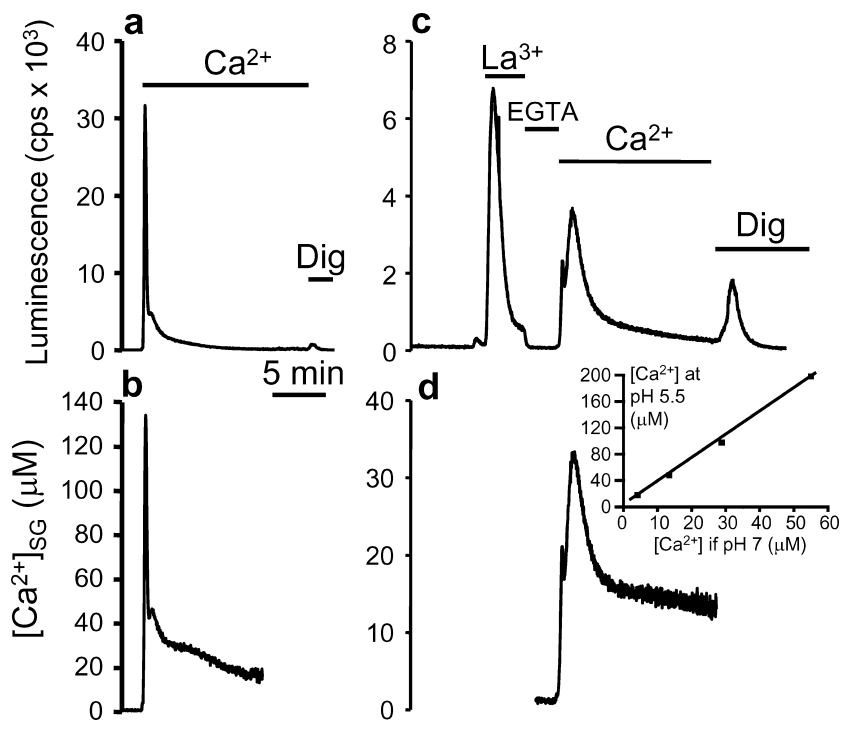

FIG. 3. Steady-state $\left[\mathrm{Ca}^{2+}\right]$ in chromaffin secretory granules $\left(\left[\mathrm{Ca}^{2+}\right]_{\mathrm{SG}}\right)$ measured with high-Ca ${ }^{2+}$-affinity vesicle-associated membrane protein (VAMP)mutated aequorin chimera (VAMP-mutaeq) in $\mathrm{Ca}^{2+}$-depleted cells. Bovine chromaffin cells expressing VAMP-mutaeq were depleted of $\mathrm{Ca}^{2+}$ before reconstitution with native coelenterazine, as described in Materials and methods. The upper panels show the luminescence records (cps, counts per second), and the lower panels the calibrated values. The luminescence was initially monitored under continuous perfusion of $\mathrm{Ca}^{2+}$-free (containing $0.5 \mathrm{mM}$ EGTA) medium. Then, standard medium containing $1 \mathrm{mM} \mathrm{Ca}^{2+}$ was perfused as indicated (a), triggering a large peak of luminescence that consumed most of the available aequorin [later addition of digitonin and $10 \mathrm{mM} \mathrm{Ca}^{2+}$ (Dig) released hardly any additional luminescence]. Calibrated values of this experiment show a large peak followed by a shoulder (b). (c and d) A similar experiment, except for the $500 \mu \mathrm{M}$ lanthanum pulse given prior to $\mathrm{Ca}^{2+}$ addition to release the luminescence of those VAMP-mutaeq molecules present on the outer side of the plasma membrane. After that, the peak induced by $\mathrm{Ca}^{2+}$ addition corresponded only to intracellular aequorin and was much smaller. These experiments were performed at $22^{\circ} \mathrm{C}$, and are representative of five to nine similar ones of each kind (the statistical data shown in the text include experiments with different stimulation protocols in the steady-state). The inset shows a comparison of the calibrations of mutated aequorin at $\mathrm{pH} 7$ and 5.5. The figure shows the correlations obtained between the calculated $\left[\mathrm{Ca}^{2+}\right]$ values (with the $\mathrm{pH} 7$ calibration, horizontal axis) and the actual values if aequorin was in a medium at $\mathrm{pH} 5.5$ (vertical axis). There is a clearly linear correlation that represents a 3- to 4 -fold increase in the $\left[\mathrm{Ca}^{2+}\right]$ values required to produce the same luminescence levels when the $\mathrm{pH}$ shifts from 7 to 5.5. Each point was calculated using four to 10 experimental sets of data obtained at both $\mathrm{pH}$ levels as described in Materials and methods.

In accordance with the confocal microscope images and with data of other authors on the subcellular localization of VAMP chimeras (Mitchell et al., 2001; Allersma et al., 2004), most of the luminescence generating the $\left[\mathrm{Ca}^{2+}\right]$ peak shown in Fig. $3 \mathrm{~d}$ must come from the vesicular space. Moreover, other organelles in the secretory pathway, such as the ER or Golgi apparatus, reach much higher $\left[\mathrm{Ca}^{2+}\right]$ values (Barrero et al., 1997; Montero et al., 1997a; Pinton et al., 1998; Alonso et al., 1999) and should produce much faster aequorin consumption. Therefore, these measures show that $\left[\mathrm{Ca}^{2+}\right]$ in the vesicular space ranges between 15 and $40 \mu \mathrm{M}$. The transient $\left[\mathrm{Ca}^{2+}\right]$ peak that precedes the steady state in the experiment shown in Fig. $3 \mathrm{~d}$ may reflect a gradient of $\left[\mathrm{Ca}^{2+}\right]$ between different vesicles, but may also be just due to an overshoot of the granule $\mathrm{Ca}^{2+}$-accumulating system during refilling. Regarding the amount of VAMP-mutaeq present in the plasma membrane, the luminescence induced by lanthanum was $31 \pm 1 \%(n=80)$ of the total luminescence. However, we have observed that for the same cell preparation, this percentage 
was always reduced to $10-20 \%$ when the duration of reconstitution with coelenterazine was longer $(2-3 \mathrm{~h})$, suggesting that plasma membrane VAMP-mutaeq is reconstituted faster than internal VAMP-mutaeq. Thus, $10-20 \%$ may be a more reasonable estimation for the amount of plasma membrane VAMP-mutaeq.

The above $\left[\mathrm{Ca}^{2+}\right]_{\mathrm{SG}}$ measured values may be an underestimation of the real ones, if we take into account the influence of vesicular $\mathrm{pH}$ in aequorin luminescence. Vesicular $\mathrm{pH}$ is thought to be around 5.5 in chromaffin cells (Winkler \& Westhead, 1980; Wu et al., 2001), and the luminescence of native aequorin is known to decrease when the $\mathrm{pH}$ is reduced (Moisescu \& Ashley, 1977). We have compared here the calibrations of mutated aequorin reconstituted with native coelenterazine at both $\mathrm{pH} 7$ and 5.5. The inset of Fig. 3 shows that decreasing the $\mathrm{pH}$ from 7 to 5.5 represents, in terms of calibration, a nearly lineal transformation of the $\left[\mathrm{Ca}^{2+}\right]$ values multiplied by a factor between 3 and 4 . Thus, if vesicular $\mathrm{pH}$ was 5.5 , the real free $\left[\mathrm{Ca}^{2+}\right]_{\mathrm{SG}}$ would be 3 - to 4 -fold higher, about $50-100 \mu \mathrm{M}$. In addition, possible changes in vesicular $\mathrm{pH}$ induced by the stimuli or during the refilling period could interfere with $\left[\mathrm{Ca}^{2+}\right]_{\mathrm{SG}}$ measurements. To estimate the importance of this interference, we used the fluorescence of the VAMP-EGFP chimera as an intragranular $\mathrm{pH}$ probe, as has been described before (Camacho et al., 2006). The single-cell traces of Fig. 4a show that no significant changes in VAMP-EGFP fluorescence were observed after addition of $\mathrm{Ca}^{2+}$ to $\mathrm{Ca}^{2+}$-depleted chromaffin cells or after the subsequent stimulation with high- $\left[\mathrm{K}^{+}\right]$depolarization. In contrast, direct alkalinization of the granules with ammonium chloride (or FCCP, data not shown) produced a fast increase in fluorescence. Figure $4 \mathrm{~b}$ shows single-cell VAMP-EGFP fluorescence data obtained in permeabilized $\mathrm{Ca}^{2+}$-depleted chromaffin cells. In that case, addition of an intracellular buffer containing $100 \mathrm{nM} \mathrm{Ca}^{2+}$, a procedure that rapidly increases intragranular $\left[\mathrm{Ca}^{2+}\right]$ (see below), produced a transient increase in VAMP-EGFP fluorescence, suggesting vesicular alkalinization, but that change was very small as compared with the large increase in fluorescence induced by ammonium chloride. Subsequent addition of $\mathrm{InsP}_{3}$ produced no effects on intragranular $\mathrm{pH}$. In conclusion, intragranular $\mathrm{pH}$ changes little during refilling with $\mathrm{Ca}^{2+}$ of the secretory granules or during cell stimulation. Thus, the observed changes in aequorin luminescence under these conditions can be confidently attributed to changes in intragranular $\left[\mathrm{Ca}^{2+}\right]$. Regarding the absolute values of $\left[\mathrm{Ca}^{2+}\right]_{\mathrm{SG}}$, in this work we used the aequorin calibration at pH 7 throughout, so the $\left[\mathrm{Ca}^{2+}\right]_{\mathrm{SG}}$ values shown may be an underestimation of up to 3- to 4-fold, as described above, depending on the actual granule $\mathrm{pH}$.

\section{Dynamics of $\left[\mathrm{Ca}^{2+}\right]_{S G}$ in intact chromaffin cells}

The prolonged steady-state $\left[\mathrm{Ca}^{2+}\right]$ values obtained under the conditions of the experiment shown in Fig. 3d are ideal for exploring the effects of different stimuli on the vesicular $\left[\mathrm{Ca}^{2+}\right]$ dynamics. Moreover, if a small part of the aequorin probe was in earlier compartments of the secretory pathway, such as the Golgi apparatus, it should be fully consumed by that time because of the higher $\left[\mathrm{Ca}^{2+}\right]$ of those compartments. Therefore, the rest of the experiments in this article were performed using this experimental approach. First, we investigated the mechanism of $\mathrm{Ca}^{2+}$ uptake and accumulation by the vesicles. Figure $5 \mathrm{a}-\mathrm{c}$ shows experiments designed to test for the presence of thapsigargin-sensitive $\mathrm{Ca}^{2+}$ pumps in this compartment. In the experiments shown in Fig. 5a, we first consumed with lanthanum all the luminescence coming from plasma membrane VAMP-mutaeq,
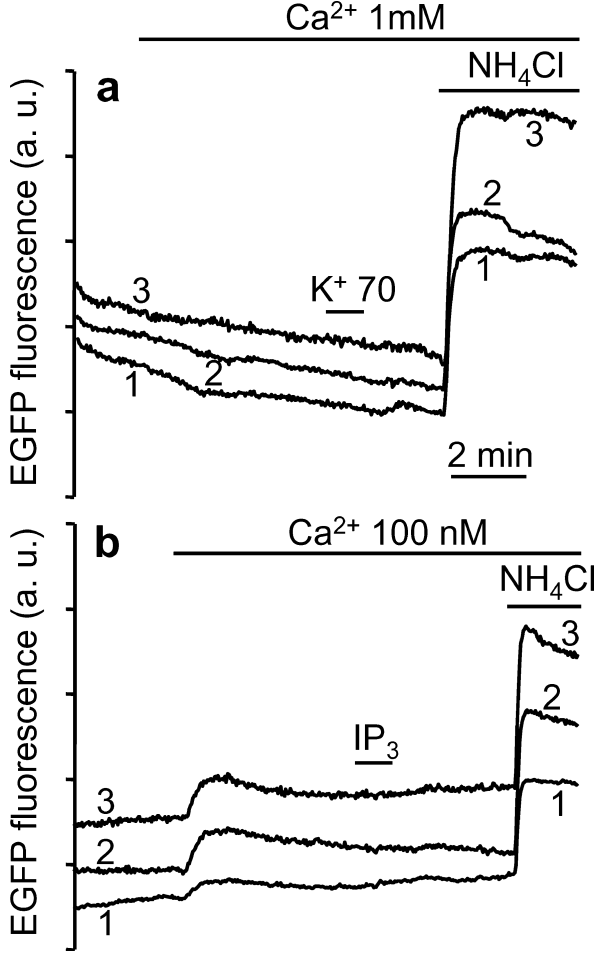

FIG. 4. Effect of $\mathrm{Ca}^{2+}$ refilling and several stimuli on intragranular $\mathrm{pH}$ measured with a vesicle-associated membrane protein (VAMP)-enhanced green fluorescent protein (EGFP) chimera. Bovine chromaffin cells expressing VAMP-EGFP were depleted of $\mathrm{Ca}^{2+}$, and then single-cell fluorescence was monitored as described in Materials and methods. (a) $1 \mathrm{mM} \mathrm{Ca}^{2+}$ was added when indicated to the extracellular medium to refill intracellular stores. Then, cells were stimulated with high- $\left[\mathrm{K}^{+}\right](70 \mathrm{mM})$ depolarization as indicated. None of these additions produced changes in the vesicular $\mathrm{pH}$. Finally, $10 \mathrm{~mm}$ ammonium chloride was added to induce a maximum $\mathrm{pH}$ increase. (b) $\mathrm{Ca}^{2+}$ depleted cells were first permeabilized as described in Materials and methods (not shown). Then, addition of an intracellular solution containing $100 \mathrm{nM} \mathrm{Ca}^{2+}$ produced a small increase in vesicular $\mathrm{pH}$, but much smaller than that induced by $10 \mathrm{mM}$ ammonium chloride. Addition of $2 \mu \mathrm{M}$ inositol 1,4,5-trisphosphate $\left(\mathrm{IP}_{3}\right)$ had no effect. In each of the panels, three representative single-cell fluorescence traces corresponding to cells from the same microscope field (labeled 1,2 and 3) are shown. These experiments are representative of nine similar ones of each kind.

and then added $\mathrm{Ca}^{2+}$ to refill the intracellular compartment, both in control cells and in cells treated for 5 min with $1 \mu \mathrm{M}$ thapsigargin before the experiment. This treatment, which irreversibly blocks SERCA pumps, largely also blocked refilling of the vesicular compartment (initial peak of $9.6 \pm 0.8 \mu \mathrm{M}, n=11$, and $\left[\mathrm{Ca}^{2+}\right]_{\mathrm{SG}}$ value $10 \mathrm{~min}$ later of only $3.2 \pm 0.4 \mu \mathrm{M}, n=11, P<0.001$ for the comparisons with the control values above, both at the peak and 10 min later), suggesting that VAMP-containing granules accumulate $\mathrm{Ca}^{2+}$ through this kind of $\mathrm{Ca}^{2+}$ pump. Further evidence for this idea was obtained from the effect of other two SERCA inhibitors, BHQ (Fig. 5b) and cyclopiazonic acid (CPA) (Fig. 5c). The figures show representative experiments in which addition of these inhibitors produced a rapid decrease in $\left[\mathrm{Ca}^{2+}\right]_{\mathrm{SG}}(\mathrm{BHQ}$, from $19 \pm 3 \mu \mathrm{M}$ to $6 \pm 1 \mu \mathrm{M}, n=8, P<0.001 ; \mathrm{CPA}$, from $22 \pm 6 \mu \mathrm{M}$ to $8 \pm 1 \mu \mathrm{M}$, $n=5, P<0.05$ ), which was nearly complete in about $1 \mathrm{~min}$. This effect was rapidly reversible in the case of BHQ and also reversible, although more slowly, in the case of CPA. Therefore, secretory granules require the continuous activity of SERCA pumps to maintain the intravesicular $\left[\mathrm{Ca}^{2+}\right]$. 


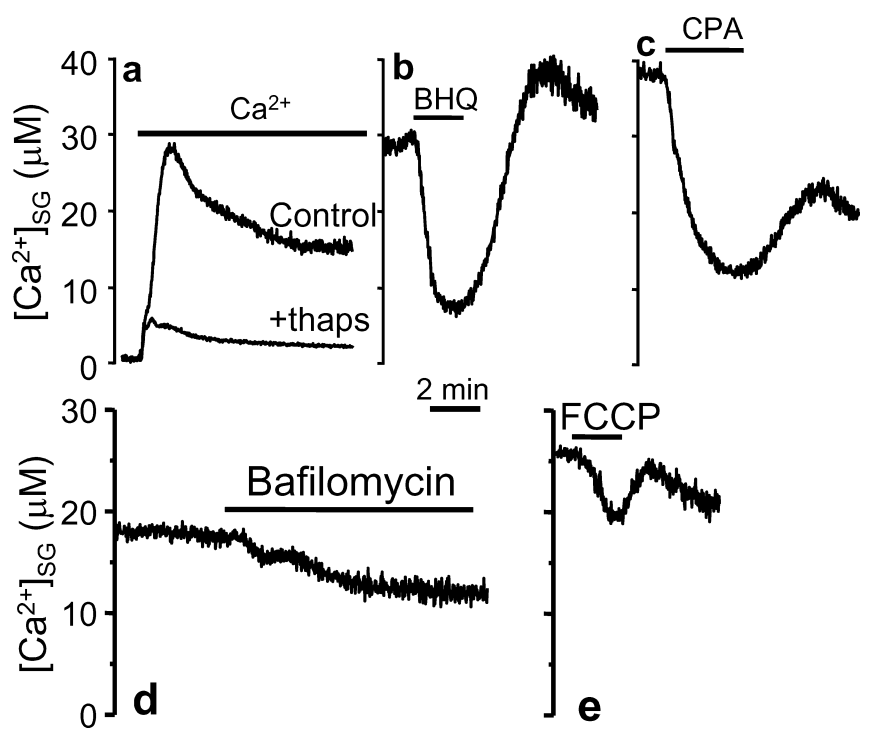

FIG. 5. Mechanisms of $\mathrm{Ca}^{2+}$ accumulation by the vesicles. Bovine chromaffin cells expressing vesicle-associated membrane protein (VAMP)-mutated aequorin chimera (VAMP-mutaeq) were depleted of $\mathrm{Ca}^{2+}$ before reconstitution with native coelenterazine, and the luminescence was initially monitored under continuous perfusion with $\mathrm{Ca}^{2+}$-free (containing $0.5 \mathrm{mM}$ EGTA) medium. A pulse of $500 \mu \mathrm{M} \mathrm{La}^{3+}$ was given to release the luminescence of the probe present in the plasma membrane (not shown). Then, after a 5-min wash with $\mathrm{Ca}^{2+}$-free medium, standard medium containing $1 \mathrm{mM} \mathrm{Ca}^{2+}$ was perfused to refill the granules with $\mathrm{Ca}^{2+}$, as indicated in (a). In the trace labeled '+thaps', it can be observed that refilling was largely blocked in cells treated with $1 \mu \mathrm{M}$ thapsigargin for $5 \mathrm{~min}$ prior to the experiment. In (b), (c), (d) and (e), either $10 \mu \mathrm{M} t$-butyl benzohydroquinone (BHQ), $10 \mu \mathrm{M}$ cyclopiazonic acid (CPA), $100 \mathrm{nM}$ bafilomycin or $2 \mu \mathrm{M}$ FCCP was added as indicated when the secretory granule $\left[\mathrm{Ca}^{2+}\right]\left(\left[\mathrm{Ca}^{2+}\right]_{\mathrm{SG}}\right)$ reached steady state. All of these treatments released $\mathrm{Ca}^{2+}$ from the vesicles. These experiments are representative of five to 13 similar ones of each kind.

We then explored the effect of bafilomycin, an inhibitor of the vesicular $\mathrm{H}^{+}$-ATPase, on $\left[\mathrm{Ca}^{2+}\right]_{\mathrm{SG}}$. As shown in Fig. $5 \mathrm{~d}$, addition of bafilomycin induced a small and slow decrease in $\left[\mathrm{Ca}^{2+}\right]_{\mathrm{SG}}$. The rate of $\left[\mathrm{Ca}^{2+}\right]_{\mathrm{SG}}$ decrease changed from $0.37 \pm 0.06 \mu \mathrm{M} / \mathrm{min}$ to $1.1 \pm 0.2 \mu \mathrm{M} / \mathrm{min}(n=5, P<0.01)$ after the addition of $100 \mathrm{nM}$ bafilomycin. However, we must take into account the fact that bafilomycin also produces a slow increase in the vesicular $\mathrm{pH}(\mathrm{Wu}$ et al., 2001; Camacho et al., 2006) that should considerably increase aequorin luminescence (depending on the resting granular $\mathrm{pH}$; see above). Thus, the small decrease in $\left[\mathrm{Ca}^{2+}\right]_{\mathrm{SG}}$ observed may in fact reflect a much larger drop, masked by the $\mathrm{pH}$ change. Finally, a direct collapse of the vesicular $\mathrm{H}^{+}$gradient with the protonophore FCCP also produced a small drop in vesicular $\left[\mathrm{Ca}^{2+}\right]$ (from $14 \pm 2$ to $11 \pm 2 \mu \mathrm{M}$, $P>0.05$, increasing again after FCCP washout to $16 \pm 3 \mu \mathrm{M}, n=13$; see Fig. 5e). The differences in this case were not statistically significant, because of the variability in the initial $\left[\mathrm{Ca}^{2+}\right]$, but the pattern of the response was the same in all the experiments. Together with the effect of bafilomycin, this suggests that the vesicular $\mathrm{H}^{+}$ gradient may partially contribute to maintain the steady-state vesicular $\left[\mathrm{Ca}^{2+}\right]$, perhaps through the activity of an $\mathrm{H}^{+} / \mathrm{Ca}^{2+}$ exchanger. This mechanism could also be responsible for the small vesicular $\mathrm{Ca}^{2+}$ uptake occurring in thapsigargin-treated cells (Fig. 5a). The experiments of Fig. 5 also show the range of variability in the resting vesicular $\left[\mathrm{Ca}^{2+}\right]$ among different single experiments, although mean values were quite similar (see above).

We then studied the effect of several chromaffin cell agonists on vesicular $\left[\mathrm{Ca}^{2+}\right]$. In Fig. 6a, we show the effect of high- $\left[\mathrm{K}^{+}\right]$

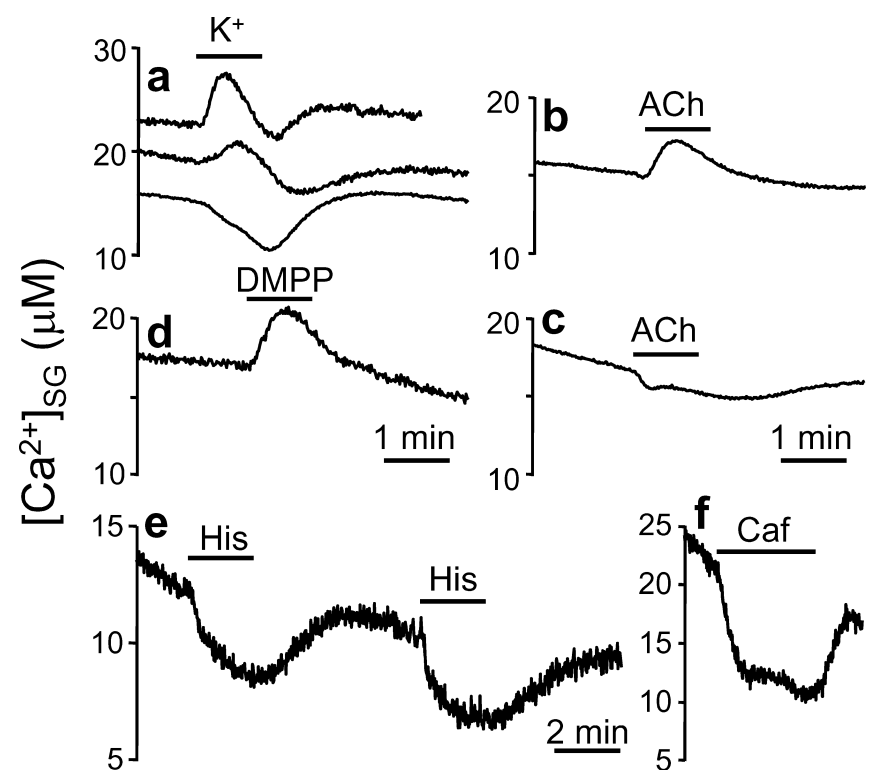

FIG. 6. Effect of high- $\left[\mathrm{K}^{+}\right]$depolarization, acetylcholine (ACh) and 1,1dimethyl-4-phenyl-piperazinium iodide (DMPP) on secretory granule $\left[\mathrm{Ca}^{2+}\right]$ $\left(\left[\mathrm{Ca}^{2+}\right]_{\mathrm{SG}}\right)$. Initial experimental details as in Fig. 5. When the $\left[\mathrm{Ca}^{2+}\right]_{\mathrm{SG}}$ reached steady state, medium containing either $70 \mathrm{mM} \mathrm{K}^{+}$(a), $100 \mu \mathrm{M} \mathrm{ACh}$ (b and c), $10 \mu \mathrm{M}$ DMPP (d), $100 \mu \mathrm{M}$ histamine (His, e) or $20 \mathrm{mM}$ caffeine (Caf, f) were added as indicated. Histamine and caffeine released $\mathrm{Ca}^{2+}$ from the vesicles, DMPP increased vesicular $\left[\mathrm{Ca}^{2+}\right]$, and high- $\left[\mathrm{K}^{+}\right]$and $\mathrm{ACh}$ produced more variable responses (see text). These experiments are representative of five to 21 similar ones of each kind.

depolarization. The three different traces are representative of the different responses that we obtained. In some cell preparations (nine of 29 experiments, 31\%), high- $\left[\mathrm{K}^{+}\right]$depolarization induced mainly a transient increase in $\left[\mathrm{Ca}^{2+}\right]_{\mathrm{SG}}$ (from $13.6 \pm 1.4$ to $21 \pm 2 \mu \mathrm{M}, n=9$, $P<0.01$ ), in others (12 of 29 experiments, $41 \%$ ), the response was mainly a transient decrease in $\left[\mathrm{Ca}^{2+}\right]_{\mathrm{SG}}$ (from $19.5 \pm 1.2$ to $15.0 \pm 0.6 \mu \mathrm{M}, n=12, P<0.005)$, and finally we also obtained (eight of 29 experiments, 28\%) a mixed response, an initial increase followed by a later decrease in $\left[\mathrm{Ca}^{2+}\right]_{\mathrm{SG}}$ with final recovery to the initial levels (an initial increase from $13.7 \pm 1.9$ to $16.1 \pm 2.1 \mu \mathrm{M}$, $P>0.05$, a decrease to $11.8 \pm 2.0 \mu \mathrm{M}$, and a final recovery to $13.9 \pm 2.2 \mu \mathrm{M}, n=8$ ). In the case of the mixed response, these changes were not statistically significant, but again the pattern of the response in all of these experiments was the same as that shown in Fig. 6a. A similar variable response was obtained when the natural agonist, acetylcholine (ACh), was used, although in this case the increase in $\left[\mathrm{Ca}^{2+}\right]_{\mathrm{SG}}$ was the predominant response (21 of 28 experiments, $75 \%$, mean increase from $17.3 \pm 0.8$ to $24.3 \pm 1.6 \mu \mathrm{M}$, $P<0.001)$. In five of 28 experiments $(18 \%)$, the effect was the opposite; a small decrease in $\left[\mathrm{Ca}^{2+}\right]_{\mathrm{SG}}$ (mean decrease from $15.1 \pm 2.2$ to $13.8 \pm 2.2 \mu \mathrm{M}, P>0.05$ ), which was not statistically significant. Only in two experiments was a mixed response observed. Figure $6 \mathrm{~b}$ and $\mathrm{c}$ shows representative traces demonstrating the two main effects of this agonist. The explanation for this heterogeneous behavior may perhaps be the presence of several populations of vesicles responding differently to the stimulus, some of them responding with an activation of SERCA pumps, and some of them responding with an activation of $\mathrm{Ca}^{2+}$-induced $\mathrm{Ca}^{2+}$ release mechanisms. Stimulation of different cell preparations could preferentially activate one or the other mechanism. On the other hand, the nicotinic agonist 1,1-dimethyl-4-phenylpiperazinium iodide (DMPP) always induced an increase in $\left[\mathrm{Ca}^{2+}\right]_{\mathrm{SG}}$ (mean increase from $15.4 \pm 0.7 \mu \mathrm{M}$ to $20.3 \pm 1.4 \mu \mathrm{M}, n=14$, 
$P<0.005$; see Fig. 6d), whereas the $\mathrm{InsP}_{3}$-producing agonist histamine always induced a decrease in $\left[\mathrm{Ca}^{2+}\right]_{\mathrm{SG}}$ (mean decrease from $10.4 \pm 0.6$ to $7.4 \pm 0.5 \mu \mathrm{M}, n=11, P<0.0051$; see Fig. 6e). Similarly, addition of the RyR activator caffeine was also effective in releasing $\mathrm{Ca}^{2+}$ from the vesicles in intact cells (mean decrease from $13.7 \pm 1.9$ to $8.6 \pm 1.6 \mu \mathrm{M}, n=10, P<0.05$; see Fig. 6 f).

\section{Dynamics of $\left[\mathrm{Ca}^{2+}\right]_{S G}$ in permeabilized chromaffin cells}

To investigate further the dynamics of $\left[\mathrm{Ca}^{2+}\right]_{\mathrm{SG}}$ and the mechanisms of $\mathrm{Ca}^{2+}$ uptake and release from the vesicles, we performed several experiments in permeabilized cells, in which the intracellular medium can be easily manipulated. To avoid interference from the VAMPmutaeq chimera present in the plasma membrane, a pulse of lanthanum was always given prior to permeabilization. Then, cells were permeabilized with digitonin, and an intracellular medium containing a $100 \mathrm{nM} \mathrm{Ca}^{2+}$ buffer was perfused to mimic the physiological $\left[\mathrm{Ca}^{2+}\right]$ in the cytosol. The control traces in Fig. 7a and $\mathrm{b}$ show that perfusion of the $\mathrm{Ca}^{2+}$ buffer induced a rapid increase in vesicular $\left[\mathrm{Ca}^{2+}\right]$, which reached a peak around $40-50 \mu \mathrm{M}$ (43 $\pm 4 \mu \mathrm{M}, n=57$ ), followed by a slower decrease down to a steady state around $10 \mu \mathrm{M}(9.2 \pm 0.3 \mu \mathrm{M}, n=55,10 \mathrm{~min}$ after the peak). The kinetics were very similar to those found in intact cells after perfusion of $\mathrm{Ca}^{2+}$-containing medium (Figs 3 and 5). In addition, the increase in vesicular $\left[\mathrm{Ca}^{2+}\right]$ was also almost completely blocked by pretreatment of the cells with thapsigargin (Fig. 7a; peak of $2.2 \pm 0.5$ $\mu \mathrm{M}, n=10$, and $\left[\mathrm{Ca}^{2+}\right]_{\mathrm{SG}}$ value $10 \mathrm{~min}$ later $1.1 \pm 0.2 \mu \mathrm{M}, n=10$, $P<0.001$ for the comparison with the corresponding control values above), confirming that SERCA pumps are mainly responsible for

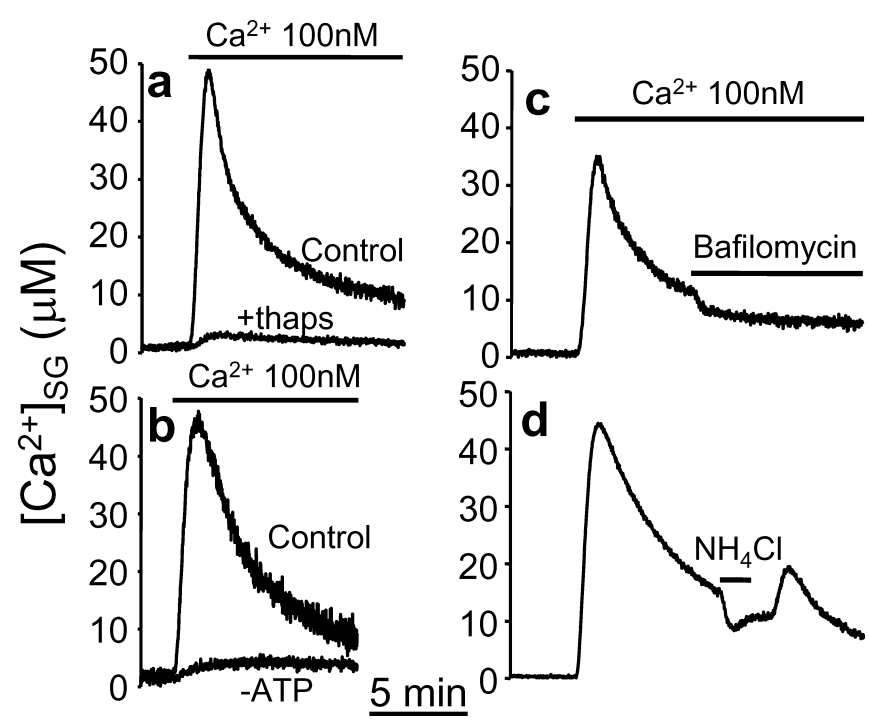

FIG. 7. Mechanisms of vesicular $\mathrm{Ca}^{2+}$ uptake in permeabilized chromaffin cells. Bovine chromaffin cells expressing vesicle-associated membrane protein (VAMP)-mutated aequorin chimera (VAMP-mutaeq) were depleted of $\mathrm{Ca}^{2+}$ and reconstituted with native coelenterazine, and the luminescence was initially monitored in $\mathrm{Ca}^{2+}$-free medium. A pulse of $500 \mu \mathrm{M} \mathrm{\textrm {La } ^ { 3 + }}$ was then given, followed by a 5 -min wash with $\mathrm{Ca}^{2+}$-free medium and then by permeabilization as described in Materials and methods. Then, intracellular medium containing a $100 \mathrm{nM} \mathrm{Ca}^{2+}$ buffer was perfused to refill the granules with $\mathrm{Ca}^{2+}$, generating a peak of secretory granule $\left[\mathrm{Ca}^{2+}\right]\left(\left[\mathrm{Ca}^{2+}\right]_{\mathrm{SG}}\right)$. Pretreatment of the cells with $1 \mu \mathrm{M}$ thapsigargin for 5 min (+thaps, a) or perfusion with medium lacking ATP and containing $5 \mu \mathrm{M}$ oligomycin (-ATP, b) largely blocked refilling. (c) and (d) show that $100 \mathrm{~nm}$ bafilomycin or $10 \mathrm{~mm}$ ammonium chloride released $\mathrm{Ca}^{2+}$ from the vesicles when added after $\mathrm{Ca}^{2+}$ refilling. These experiments are representative of four to 10 similar ones of each kind.
$\mathrm{Ca}^{2+}$ uptake into the vesicular compartment. Consistently, the increase in $\left[\mathrm{Ca}^{2+}\right]_{\mathrm{SG}}$ was also blocked in the absence of ATP in the perfusion medium (Fig. 7b; peak of $3.3 \pm 0.4 \mu \mathrm{M}, n=6$, and $\left[\mathrm{Ca}^{2+}\right]_{\mathrm{SG}}$ value 10 min later $2.7 \pm 0.3 \mu \mathrm{M}, n=6, P<0.001$ for the comparison with control values), confirming the requirement for an ATP-dependent mechanism for $\mathrm{Ca}^{2+}$ uptake into the vesicles.

As shown above for intact cells, addition of the $\mathrm{H}^{+}$-ATPase inhibitor bafilomycin to permeabilized cells induced a small decrease in vesicular $\left[\mathrm{Ca}^{2+}\right]$ (from $10.7 \pm 0.8 \mu \mathrm{M}$ to $7.7 \pm 0.3 \mu \mathrm{M}$, $n=5, P<0.01$; see Fig. $7 \mathrm{c}$ ). This effect may be related to the $\mathrm{pH}$ changes induced by this inhibitor in the granules, as ammonium chloride produced similar effects (decrease from $11.8 \pm 1.9$ to $6.6 \pm 1.0 \mu \mathrm{M}, \quad P<0.05$, followed by a rapid overshoot to $13.1 \pm 2.6 \mu \mathrm{M}$ after washout, $n=4$; see Fig. $7 \mathrm{~d}$ ). As mentioned above, $\mathrm{Ca}^{2+}$ release induced by these agents may be underestimated, taking into account that the $\mathrm{pH}$ change that they induce should lead to an increase in aequorin luminescence. Finally, we tested the effect in permeabilized cells of $\mathrm{InsP}_{3}$, caffeine, cADPR, NAADP, and micromolar $\mathrm{Ca}^{2+}$. The upper panels of Fig. 8 depict representative experiments showing that both $\mathrm{InsP}_{3}$ and caffeine were able to induce fast and reversible $\mathrm{Ca}^{2+}$ release from the vesicles, suggesting the presence in the granules of both $\mathrm{InsP}_{3}$

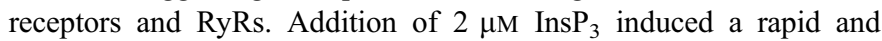
reversible decrease of $\left[\mathrm{Ca}^{2+}\right]_{\mathrm{SG}}$ from $10.5 \pm 0.8$ to $5.5 \pm 0.5 \mu \mathrm{M}$ $(n=14, P<0.001)$. Addition of $20 \mathrm{~mm}$ caffeine also induced a reversible decrease of $\left[\mathrm{Ca}^{2+}\right]_{\mathrm{SG}}$ from $12.7 \pm 3.5$ to $7.7 \pm 2.0 \mu \mathrm{M}$ $(n=4, P>0.05)$. The difference in this case was not statistically significant, due to the variability in the initial $\left[\mathrm{Ca}^{2+}\right]$, but the effect was consistently found in all the experiments (in terms of percentages, the mean $\left[\mathrm{Ca}^{2+}\right]_{\mathrm{SG}}$ decrease induced by caffeine was $39.8 \pm 2.5 \%, n=4)$. The experiments included in the lower panels

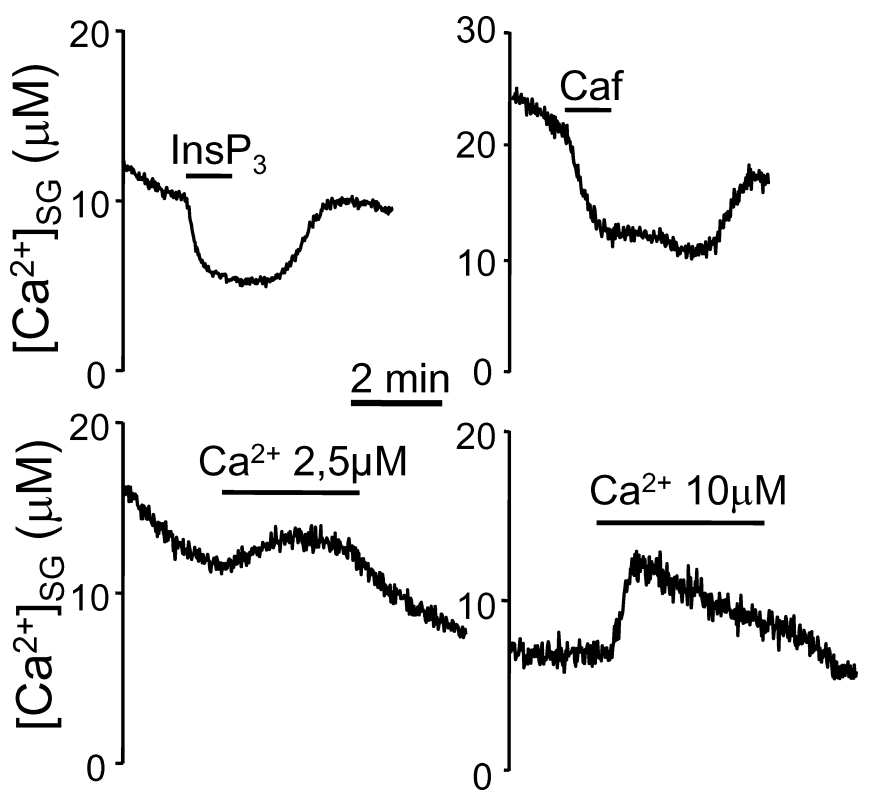

FIG. 8. Effects of inositol 1,4,5-trisphosphate $\left(\operatorname{InsP}_{3}\right)$, caffeine $(\mathrm{Caf})$ and $\mathrm{Ca}^{2+}$ on secretory granule $\left[\mathrm{Ca}^{2+}\right]\left(\left[\mathrm{Ca}^{2+}\right]_{\mathrm{SG}}\right)$. Initial experimental details as in Fig. 7. The intracellular medium containing a $100 \mathrm{nM} \mathrm{Ca}^{2+}$ buffer was perfused until a quasi-steady state was reached (not shown). After this, addition of either $2 \mu \mathrm{M}$ $\mathrm{InsP}_{3}$ or $50 \mathrm{mM}$ caffeine induced release of $\mathrm{Ca}^{2+}$ from the vesicles, whereas perfusion of $\mathrm{Ca}^{2+}$ buffers prepared to obtain 2.5 or $10 \mu \mathrm{M}$ free $\mathrm{Ca}^{2+}$ induced an increase of $\left[\mathrm{Ca}^{2+}\right]_{\mathrm{SG}}$. These experiments are representative of four to 14 similar ones of each kind. 
of Fig. 8 show that perfusion of medium containing either 2.5 or $10 \mu \mathrm{M}$ free $\mathrm{Ca}^{2+}$ produced a transient increase in $\left[\mathrm{Ca}^{2+}\right]_{\mathrm{SG}}$, which was larger at the higher $\left[\mathrm{Ca}^{2+}\right]$. Perfusion of medium containing $2.5 \mu \mathrm{M} \mathrm{Ca}^{2+}$ induced a small increase in $\left[\mathrm{Ca}^{2+}\right]_{\mathrm{SG}}$ from $11.3 \pm 1.0$ to $13.5 \pm 1.0 \mu \mathrm{M}(n=6)(19 \%$ increase $)$, which was not statistically significant $(P>0.05)$. In the case of the $10 \mu \mathrm{M} \mathrm{Ca}{ }^{2+}$ medium, $\left[\mathrm{Ca}^{2+}\right]_{\mathrm{SG}}$ increased from $9.6 \pm 1.8$ to $16.5 \pm 2.9 \mu \mathrm{M}(n=8)(72 \%$ increase, $P<0.05$ ), whereas neither $5 \mu \mathrm{M}$ cADPR nor $100 \mathrm{nM}$ NAADP produced any effect on $\left[\mathrm{Ca}^{2+}\right]_{\mathrm{SG}}$ (data not shown).

\section{Discussion}

In this study, we investigated the dynamics of $\left[\mathrm{Ca}^{2+}\right]$ inside the secretory granules of primary cultures of chromaffin cells, using a targeted VAMP-mutated aequorin (VAMP-mutaeq) chimera. The same chimera has been used previously in MIN6 $\beta$-cells (Mitchell et al., 2001, 2003), INS-1E cells (Iezzi et al., 2005), and PC12 cells (Moreno et al., 2005). In all of these studies, VAMP-mutaeq was reconstituted with the semisynthetic cofactor coelenterazine $\mathrm{n}$, generating an aequorin chimera with very low $\mathrm{Ca}^{2+}$ sensitivity. This type of aequorin was originally designed and used to monitor the high $\left[\mathrm{Ca}^{2+}\right]$ found in the ER, around $500 \mu \mathrm{M}$ (Montero et al., 1997a). However, the $\left[\mathrm{Ca}^{2+}\right]$ found in the secretory vesicles is much lower, around 50$100 \mu \mathrm{M}$. This range of concentrations is in the lower limit of detection for that aequorin form, particularly if we take into account that the acidic granular $\mathrm{pH}$ reduces aequorin luminescence 3- to 4-fold, providing apparent $\left[\mathrm{Ca}^{2+}\right]_{\mathrm{SG}}$ values of only $20-30 \mu \mathrm{M}$. Thus, we have now found that it is much better to use an aequorin form with higher $\mathrm{Ca}^{2+}$ affinity to follow vesicular $\mathrm{Ca}^{2+}$ dynamics, and particularly to detect $\mathrm{Ca}^{2+}$ release from the vesicles.

We used here the same VAMP-mutaeq, but reconstituted with native coelenterazine. This combination increases by one order of magnitude the $\mathrm{Ca}^{2+}$ affinity of the probe and allows the monitoring of $\left[\mathrm{Ca}^{2+}\right]_{S G}$ dynamics with much more sensitivity. Moreover, reducing the temperature to $22^{\circ} \mathrm{C}$ allowed fine tuning of the sensitivity in order to monitor adequately the dynamics of $\left[\mathrm{Ca}^{2+}\right]_{\mathrm{SG}}$ during stimulation. In fact, finding the aequorin form with the correct sensitivity is a critical point. In a recent study, a chromogranin-aequorin chimera with even higher $\mathrm{Ca}^{2+}$ affinity was used to monitor $\left[\mathrm{Ca}^{2+}\right]$ in the secretory vesicles of $\mathrm{PC} 12$ cells (Mahapatra et al., 2004). In that case, the native form of aequorin was used, and it was reconstituted with native coelenterazine, generating an aequorin form with very high $\mathrm{Ca}^{2+}$ affinity. That aequorin form, ideal for measuring cytosolic $\left[\mathrm{Ca}^{2+}\right]$, becomes rapidly saturated and consumed when $\left[\mathrm{Ca}^{2+}\right]$ rises to the micromolar range, as occurs in the secretory granules. This emphasizes again the importance of choosing the right aequorin form, adapted to the $\left[\mathrm{Ca}^{2+}\right]$ in the compartment to which it is targeted. Otherwise, large discrepancies from the real $\left[\mathrm{Ca}^{2+}\right]$ values can appear, as we have previously found using ER-targeted aequorins with different $\mathrm{Ca}^{2+}$ affinities (Montero et al., 1997b).

Considerable evidence has previously been provided indicating that either VAMP-aequorin or VAMP-EGFP chimeras are correctly targeted to the secretory vesicles in different secretory cell types (Mitchell et al., 2001, 2003; Allersma et al., 2004). We have shown here by confocal microscopy that expression of VAMP-EGFP in chromaffin cells provides, in fact, a typical granular pattern, although a certain amount of fluorescence is always associated with the plasma membrane, as can be expected for a protein that follows the secretory pathway. The presence of VAMP-mutaeq in the plasma membrane was confirmed by the effect of lanthanum, an impermeable cation that immediately produced a peak of aequorin luminescence when added to the extracellular medium. Then, once the luminescence from the plasma membrane VAMP-mutaeq had been released with lanthanum, the remaining intracellular luminescence was present in a compartment with an apparent $\left[\mathrm{Ca}^{2+}\right]$ around $20-30 \mu \mathrm{M}$, much higher than in the cytosol but still one order of magnitude lower than in other compartments of the secretory pathway, such as the ER or Golgi apparatus.

The results of this study show several important and novel characteristics of $\left[\mathrm{Ca}^{2+}\right]$ fluxes in secretory vesicles. The first question regards the free $\left[\mathrm{Ca}^{2+}\right]$ in the vesicles. During $\mathrm{Ca}^{2+}$ refilling of the vesicular space, the $\left[\mathrm{Ca}^{2+}\right]_{\mathrm{SG}}$ traces showed a peak at $40 \mu \mathrm{M}$ followed by a continuously decreasing trace in the 15-20 $\mu \mathrm{M}$ range (Fig. 3). This behavior suggests that the $\left[\mathrm{Ca}^{2+}\right]$ in the vesicular population is not homogeneous, so that aequorin is first consumed in higher-[Ca $\left.{ }^{2+}\right]$ compartments and the final luminescence comes mainly from the lower- $\left[\mathrm{Ca}^{2+}\right]$ compartments. Taking into account the influence on aequorin luminescence of the acidic intragranular $\mathrm{pH}$ of 5.5 (Winkler \& Westhead, 1980; Wu et al., 2001), the real values for the free $\left[\mathrm{Ca}^{2+}\right]_{\mathrm{SG}}$ should then range between 50 and $100 \mu \mathrm{M}$. Vesicular $\mathrm{pH}$ significantly modifies aequorin luminescence, but it appears to change little during $\mathrm{Ca}^{2+}$ refilling of the granules or during stimulation with high $\left[\mathrm{K}^{+}\right]$in intact cells or with $\mathrm{InsP}_{3}$ in permeabilized cells. Thus, the aequorin luminescence changes observed under these conditions can be clearly attributed to changes in $\left[\mathrm{Ca}^{2+}\right]_{\mathrm{SG}}$. Similarly, the increases in $\left[\mathrm{Ca}^{2+}\right]_{\mathrm{SG}}$ induced by the nicotinic agonist DMPP and by $\mathrm{Ca}^{2+}$ in permeabilized cells are not due to $\mathrm{pH}$ changes, as these stimuli have been shown to produce only some acidification (Camacho et al., 2006). On the other hand, the effects of vesicular $\mathrm{pH}$ changes on aequorin luminescence must be taken into account to interpret the effects of bafilomycin or FCCP, which are known to increase vesicular $\mathrm{pH}$. In both cases, the observed release of $\mathrm{Ca}^{2+}$ from the vesicles may be underestimated because of the concurrent $\mathrm{pH}$ increase.

The measured values of $\left[\mathrm{Ca}^{2+}\right]_{\mathrm{SG}}$ represent only a tiny fraction of the total $\mathrm{Ca}^{2+}$ contained in the granules, which is around $20-40 \mathrm{mM}$ (Fasolato et al., 1991; Yoo \& Albanesi, 1991), and is thus nearly 1000 -fold the free $\left[\mathrm{Ca}^{2+}\right]_{\mathrm{SG}}$ measured here. This $\mathrm{Ca}^{2+}$ is bound in part to chromogranins, the most abundant proteins in the chromaffin vesicles ( $40 \%$ of the soluble intravesicular proteins) (Simon \& Aunis, 1989), which bind $152 \mathrm{nmol} \mathrm{Ca}{ }^{2+} / \mathrm{mg}$ protein with a $K_{\mathrm{d}}$ of $54 \mu \mathrm{M}$ (Bulenda \& Gratzl, 1985; Simon \& Aunis, 1989; Yoo \& Albanesi, 1991). In addition, the vesicles also contain large amounts of ATP (130 mM) (Winkler \& Westhead, 1980), which may also bind significant amounts of $\mathrm{Ca}^{2+}$.

Our data provide evidence that $\mathrm{Ca}^{2+}$ accumulation in the vesicles is ATP-dependent and takes place mainly via SERCA-type pumps that are sensitive to the usual inhibitors: thapsigargin, BHQ, and CPA. Inhibition of the $\mathrm{H}^{+}$-ATPase with bafilomycin produced only slow $\mathrm{Ca}^{2+}$ release from the vesicles; this effect was mimicked by agents able to alkalinize the vesicles, such as the protonophore FCCP or ammonium chloride. These effects could be explained by the operation of an $\mathrm{H}^{+} / \mathrm{Ca}^{2+}$ exchanger, whose presence in the vesicular membrane has been suggested previously for synaptic vesicles (Goncalves et al., 1998, 1999) and yeast vacuoles (Ungermann et al., 1999). However, this system would make only a minor contribution to secretory granule $\mathrm{Ca}^{2+}$ uptake in these cells, perhaps because of its low $\mathrm{Ca}^{2+}$ affinity (Goncalves et al., 1998, 1999). The presence of thapsigargin-sensitive $\mathrm{Ca}^{2+}$ pumps in the secretory vesicles was surprising, as this compartment is usually considered to have thapsigargin-insensitive secretory pathway $\mathrm{Ca}^{2+}$-ATPases. In fact, in the original experiments performed with the same VAMP-aequorin chimera in the MIN-6 $\beta$-cell line, $\mathrm{Ca}^{2+}$ uptake into the vesicles was insensitive to thapsigargin or CPA. However, thapsigargin-sensitive $\mathrm{Ca}^{2+}$ uptake into the vesicles of $\mathrm{PC} 12$ cells has been also described in a previous study using a high-Ca ${ }^{2+}$ affinity chromogranin-aequorin chimera (Mahapatra et al., 2004). In addition, the presence of acidic $\mathrm{Ca}^{2+}$ stores (probably corresponding to 
dense-core insulin storage granules) that are sensitive to thapsigargin, BHQ and CPA has also been recently described in primary mouse $\beta$-cells (Duman et al., 2006).

From the physiological point of view, the main question regarding vesicular $\left[\mathrm{Ca}^{2+}\right]$ fluxes is whether the granular $\mathrm{Ca}^{2+}$ may or not be released under physiological conditions and contribute to secretion. We found here that both $\mathrm{InsP}_{3}$ and caffeine are potent activators of $\mathrm{Ca}^{2+}$ release from the granules, suggesting the presence of functional $\mathrm{InsP}_{3}$ receptors and RyRs in the vesicular membrane. The release of $\mathrm{Ca}^{2+}$ from the vesicles via $\mathrm{InsP}_{3}$ receptors was also confirmed in intact cells, where the $\mathrm{Ins}_{3}$-producing agonist histamine was able to induce a rapid and reversible $\left[\mathrm{Ca}^{2+}\right]_{\mathrm{SG}}$ decrease. In fact, the presence of $\mathrm{InsP}_{3}$ receptors in the membrane of chromaffin cell secretory granules has been a matter of debate for a long time (Yoo \& Albanesi, 1991; Pouli et al., 1998; Huh et al., 2005; Endo et al., 2006), although they have been consistently described in mast cell granules (Quesada et al., 2001, 2003) and pancreatic acinar granules (Gerasimenko et al., 1996, 2006). However, we did not find effects with cADPR, which has been shown to activate RyRs in pancreatic acinar granules (Gerasimenko et al., 1996, 2006) and MIN-6 cell granules (Mitchell et al., 2001, 2003), or with NAADP, which has also been shown to release $\mathrm{Ca}^{2+}$ from pancreatic acinar granules (Gerasimenko et al., 2006), MIN-6 cell granules (Mitchell et al., 2003), and mouse pancreatic $\beta$-cells (Duman et al., 2006). The discrepancy may perhaps be due to the cell type, as cADPR was also unable to release $\mathrm{Ca}^{2+}$ from the ER in chromaffin cells (Alonso et al., 1999).

Our data also show that stimuli such as ACh or high- $\left[\mathrm{K}^{+}\right]$ depolarization were able to induce a transient release of $\mathrm{Ca}^{2+}$ from the granules (Fig. 6). Actually, these stimuli induced a double response, an increase and/or a decrease of $\left[\mathrm{Ca}^{2+}\right]_{\mathrm{SG}}$, a phenomenon that suggests a heterogeneous response of the vesicular population. We think that it is reasonable to speculate that vesicles close to the plasma membrane, in the releasable pool, would be more prone to open their $\mathrm{InsP}_{3}$ receptors and RyRs after stimulation, because of the higher subplasmalemmal InsP $\mathrm{P}_{3}$ and $\mathrm{Ca}^{2+}$ concentrations obtained after the stimulus, whereas in more internal vesicles, activation of SERCA pumps by the increased cytosolic $\left[\mathrm{Ca}^{2+}\right]$ may be predominant, leading to $\mathrm{Ca}^{2+}$ uptake by the vesicles, a mechanism that could be important for vesicle transport and maturation. Both effects, $\mathrm{Ca}^{2+}$ release in peripheral vesicles and increasing $\mathrm{Ca}^{2+}$ uptake in internal ones, should occur simultaneously in order to have physiological significance. The effects of histamine and caffeine show that the vesicles are able to rapidly release $\mathrm{Ca}^{2+}$ in intact cells after stimulation. The mixed response would then appear as the result of the two parallel effects in the particular cell conditions of each experiment.

From a theoretical point of view, it is difficult to speculate on how important $\mathrm{Ca}^{2+}$ release from the vesicles may be for secretion as compared to the large flux of $\mathrm{Ca}^{2+}$ entering the cell during an action potential. There are still many uncertainties regarding the percentage of vesicles able to release $\mathrm{Ca}^{2+}$, the amount of $\mathrm{Ca}^{2+}$ released, the kinetics of vesicular $\mathrm{Ca}^{2+}$ buffers, etc. However, it may be useful to make some simple estimations. For example, chromaffin cells have about 20000 vesicles that each contain about 90000 calcium ions (Winkler \& Westhead, 1980). Assuming that $1 \%$ of the vesicles release $20 \%$ of their calcium ions (or $5 \%$ of the vesicles release $4 \%$ of it), this amounts to $3.6 \times 10^{6} \mathrm{Ca}^{2+}$ released $\left(6 \times 10^{-18} \mathrm{~mol}\right)$. For chromaffin cells, with a diameter of about $15 \mu \mathrm{m}$ (volume $1.7 \times 10^{-12} \mathrm{~L}$ ), this corresponds to $3.5 \mu \mathrm{mol} / \mathrm{L}$ cells. Regarding $\mathrm{Ca}^{2+}$ entry during an action potential, the average voltage-dependent $\mathrm{Ca}^{2+}$ current measured during chromaffin cell depolarization $(250 \mathrm{pA})$ (Zhou \& Neher, 1993) corresponds to about $700 \mu \mathrm{mol} / \mathrm{L}$ cell/s for a
15- $\mu$ m-diameter cell. In these cells, a typical action potential lasts $5 \mathrm{~ms}$, so the amount of $\mathrm{Ca}^{2+}$ entering the cells during an action potential would be about $3.5 \mu \mathrm{mol} / \mathrm{L}$ cell, the same as the release from the vesicles under the assumptions made above. Of course, the real figures may be different, but this simple calculation shows that vesicular $\mathrm{Ca}^{2+}$ has the potential to influence secretion. In addition, we have to take into account that the $\mathrm{Ca}^{2+}$ released from the vesicles is necessarily closer to the exocytotic sites, and thus more effective, than $\mathrm{Ca}^{2+}$ entering from outside.

Therefore, in conclusion, secretory granules in chromaffin cells have mechanisms for fast $\mathrm{Ca}^{2+}$ release (InsP $\mathrm{I}_{3}$ receptors and RyRs) and are able to release $\mathrm{Ca}^{2+}$ after cell stimulation with $\mathrm{ACh}$ or high- $\left[\mathrm{K}^{+}\right]$ depolarization. Evidence for the contribution of secretory granule $\mathrm{Ca}^{2+}$ to exocytosis has been reported before (Fossier et al., 1998; Scheenen et al., 1998; Mundorf et al., 2000; Haynes et al., 2006). Our data strongly support this hypothesis and suggest that granular $\mathrm{Ca}^{2+}$ may contribute to its own secretion.

\section{Acknowledgements}

This work was supported by grants from Ministerio de Educación y Ciencia (BFU2005-05464) and from Junta de Castilla y León (VA103A08). J. SantoDomingo and E. Hernández-SanMiguel hold FPI (Formación de Personal Investigador) and FPU (Formación de Profesorado Universitario) fellowships, respectively, from the Spanish Ministerio de Educación y Ciencia (MEC). L. Vay holds a fellowship from Fondo de Investigaciones Sanitarias (Spanish Ministerio de Sanidad). M. Camacho was making a short stay financed by his FPI fellowship from MEC. We thank Dr Ricardo Borges for helpful discussions, Elena González for excellent technical assistance, and the veterinarians of the Matadero Justino Gutiérrez of Laguna de Duero (Valladolid) for providing cow adrenal glands.

\section{Abbreviations}

$\mathrm{ACh}$, acetylcholine; BHQ, $t$-butyl benzohydroquinone; $\left[\mathrm{Ca}^{2+}\right]_{\mathrm{sG}}$, secretory granule $\left[\mathrm{Ca}^{2+}\right]$; CPA, cyclopiazonic acid; cADPR, cADP ribose; DMPP, 1,1dimethyl-4-phenyl-piperazinium iodide; EGFP, enhanced green fluorescent protein; ER, endoplasmic reticulum; Ins $\mathrm{P}_{3}$, inositol 1,4,5-trisphosphate; FCCP, carbonyl cyanide 4-(trifluoromethoxy)phenylhydrazone; NAADP, nicotinic acid adenine dinucleotide phosphate; RyR, ryanodine receptor; SERCA, sarcoendoplasmic reticulum $\mathrm{Ca}^{2+}$-ATPase; VAMP, vesicle-associated membrane protein; VAMP-mutaeq, vesicle-associated membrane protein-mutated aequorin chimera.

\section{References}

Allersma, M.W., Wang, L., Axelrod, D. \& Holz, R.W. (2004) Visualization of regulated exocytosis with a granule-membrane probe using total internal reflection microscopy. Mol. Biol. Cell, 15, 4658-4668.

Alonso, M.T., Barrero, M.J., Michelena, P., Carnicero, E., Cuchillo, I., García, A.G., García-Sancho, J., Montero, M. \& Alvarez, J. (1999) $\mathrm{Ca}^{2+}$-induced $\mathrm{Ca}^{2+}$ release in chromaffin cells seen from inside the ER with targeted aequorin. J. Cell Biol., 144, 241-254.

Alvarez, J. \& Montero, M. (2002) Measuring $\left[\mathrm{Ca}^{2+}\right]$ in the endoplasmic reticulum with aequorin. Cell Calcium, 32, 251-260.

Barrero, M.J., Montero, M. \& Alvarez, J. (1997) Dynamics of $\left[\mathrm{Ca}^{2+}\right]$ in the endoplasmic reticulum and cytoplasm of intact HeLa cells. A comparative study. J. Biol. Chem., 272, 27694-27699.

Bulenda, D. \& Gratzl, M. (1985) Matrix free $\mathrm{Ca}^{2+}$ in isolated chromaffin vesicles. Biochemistry, 24, 7760-7765.

Camacho, M., Machado, J.D., Montesinos, M.S., Criado, M. \& Borges, R (2006) Intragranular $\mathrm{pH}$ rapidly modulates exocytosis in adrenal chromaffin cells. J. Neurochem., 96, 324-334.

Duman, J.G., Chen, L., Palmer, A.E. \& Hille, B. (2006) Contributions of intracellular compartments to calcium dynamics: implicating an acidic store. Traffic, 7, 859-872.

Endo, Y., Harada, K., Fujishiro, N., Funahashi, H., Shioda, S., Prestwich, G.D., Mikoshiba, K. \& Inoue, M. (2006) Organelles containing inositol trisphosphate receptor type 2 in adrenal medullary cells. J. Physiol. Sci., 56, 415-423. 
Fasolato, C., Zottini, M., Clementi, E., Zacchetti, D., Meldolesi, J. \& Pozzan, T. (1991) Intracellular $\mathrm{Ca}^{2+}$ pools in PC12 cells. Three intracellular pools are distinguished by their turnover and mechanisms of $\mathrm{Ca}^{2+}$ accumulation, storage, and release. J. Biol. Chem., 266, 20159-20167.

Fossier, P., Diebler, M.F., Mothet, J.P., Israel, M., Tauc, L. \& Baux, G. (1998) Control of the calcium concentration involved in acetylcholine release and its facilitation: an additional role for synaptic vesicles? Neuroscience, 85, 85-91.

Garcia, A.G., Garcia de Diego, A.M., Gandia, L., Borges, R. \& Garcia-Sancho, J. (2006) Calcium signaling and exocytosis in adrenal chromaffin cells. Physiol. Rev., 86, 1093-1131.

Gerasimenko, O.V., Gerasimenko, J.V., Belan, P.V. \& Petersen, O.H. (1996) Inositol trisphosphate and cyclic ADP-ribose-mediated release of $\mathrm{Ca}^{2+}$ from single isolated pancreatic zymogen granules. Cell, 84, 473-480.

Gerasimenko, J.V., Sherwood, M., Tepikin, A.V., Petersen, O.H. \& Gerasimenko, O.V. (2006) NAADP, cADPR and $\mathrm{IP}_{3}$ all release $\mathrm{Ca}^{2+}$ from the endoplasmic reticulum and an acidic store in the secretory granule area. J. Cell Sci., 119, 226-238.

Goncalves, P.P., Meireles, S.M., Gravato, C. \& Vale, M.G. (1998) $\mathrm{Ca}^{2+}-\mathrm{H}^{+}$ antiport activity in synaptic vesicles isolated from sheep brain cortex. Neurosci. Lett., 247, 87-90.

Goncalves, P.P., Meireles, S.M., Neves, P. \& Vale, M.G. (1999) Ionic selectivity of the $\mathrm{Ca}^{2+} / \mathrm{H}^{+}$antiport in synaptic vesicles of sheep brain cortex. Brain Res. Mol. Brain Res., 67, 283-291.

Haigh, J.R., Parris, R. \& Phillips, J.H. (1989) Free concentrations of sodium, potassium and calcium in chromaffin granules. Biochem. J., 259, 485-491.

Haynes, C.L., Buhler, L.A. \& Wightman, R.M. (2006) Vesicular $\mathrm{Ca}^{2+}$-induced secretion promoted by intracellular $\mathrm{pH}$-gradient disruption. Biophys. Chem., 123, 20-24.

Huh, Y.H., Yoo, J.A., Bahk, S.J. \& Yoo, S.H. (2005) Distribution profile of inositol 1,4,5-trisphosphate receptor isoforms in adrenal chromaffin cells. FEBS Lett., 579, 2597-2603.

Hutton, J.C. (1989) The insulin secretory granule. Diabetologia, 32, 271-281.

Iezzi, M., Theander, S., Janz, R., Loze, C. \& Wollheim, C.B. (2005) SV2A and $\mathrm{SV} 2 \mathrm{C}$ are not vesicular $\mathrm{Ca}^{2+}$ transporters but control glucose-evoked granule recruitment. J. Cell Sci., 118, 5647-5660.

Mahapatra, N.R., Mahata, M., Hazra, P.P., McDonough, P.M., O’Connor, D.T. \& Mahata, S.K. (2004) A dynamic pool of calcium in catecholamine storage vesicles: exploration in living cells by a novel vesicle-targeted chromogranin A/aequorin chimeric photoprotein. J. Biol. Chem., 279, 51107-51121.

Marley, P.D., Bales, P.J., Zerbes, M., Powis, D.A. \& O'Farrell, M. (2000) Mobilizing store $\mathrm{Ca}^{2+}$ in the presence of $\mathrm{La}^{3+}$ evokes exocytosis in bovine chromaffin cells. J. Neurochem., 75, 1162-1171.

Mitchell, K.J., Pinton, P., Varadi, A., Tacchetti, C., Ainscow, E.K., Pozzan, T., Rizzuto, R. \& Rutter, G.A. (2001) Dense core secretory vesicles revealed as a dynamic $\mathrm{Ca}^{2+}$ store in neuroendocrine cells with a vesicle-associated membrane protein aequorin chimaera. J. Cell Biol., 155, 41-51.

Mitchell, K.J., Lai, F.A. \& Rutter, G.A. (2003) Ryanodine receptor type I and nicotinic acid adenine dinucleotide phosphate receptors mediate $\mathrm{Ca}^{2+}$ release from insulin-containing vesicles in living pancreatic beta-cells (MIN6) J. Biol. Chem., 278, 11057-11064.

Moisescu, D.G. \& Ashley, C.C. (1977) The effect of physiologically occurring cations upon aequorin light emission. Determination of the binding constants. Biochim. Biophys. Acta, 460, 189-205.
Montero, M., Barrero, M.J. \& Alvarez, J. (1997a) $\left[\mathrm{Ca}^{2+}\right]$ microdomains control agonist-induced $\mathrm{Ca}^{2+}$ release in intact HeLa cells. FASEB J., 11, $881-885$.

Montero, M., Alvarez, J., Scheenen, W.J., Rizzuto, R., Meldolesi, J. \& Pozzan, T. (1997b) $\mathrm{Ca}^{2+}$ homeostasis in the endoplasmic reticulum: coexistence of high and low $\left[\mathrm{Ca}^{2+}\right]$ subcompartments in intact HeLa cells. J. Cell Biol., 139, 601-611.

Moreno, A., Lobatón, C.D., SantoDomingo, J., Vay, L., HernándezSanMiguel, E., Rizzuto, R., Montero, M. \& Alvarez, J. (2005) Calcium dynamics in catecholamine-containing secretory vesicles. Cell Calcium, 37, 555-564.

Moro, M.A., López, M.G., Gandía, L., Michelena, P. \& García, A.G. (1990) Separation and culture of living adrenaline- and noradrenaline-containing cells from bovine adrenal medullae. Anal. Biochem., 185, 243-248.

Mundorf, M.L., Troyer, K.P., Hochstetler, S.E., Near, J.A. \& Wightman, R.M. (2000) Vesicular $\mathrm{Ca}^{2+}$ participates in the catalysis of exocytosis. J. Biol. Chem., 275, 9136-9142.

Pinton, P., Pozzan, T. \& Rizzuto, R. (1998) The Golgi apparatus is an inositol 1,4,5-trisphosphate-sensitive $\mathrm{Ca}^{2+}$ store, with functional properties distinct from those of the endoplasmic reticulum. EMBO J., 17, 52985308.

Pouli, A.E., Emmanouilidou, E., Zhao, C., Wasmeier, C., Hutton, J.C. \& Rutter, G.A. (1998) Secretory-granule dynamics visualized in vivo with a phogringreen fluorescent protein chimaera. Biochem. J., 333, 193-199.

Quesada, I., Chin, W.C., Steed, J., Campos-Bedolla, P. \& Verdugo, P. (2001) Mouse mast cell secretory granules can function as intracellular ionic oscillators. Biophys. J., 80, 2133-2139.

Quesada, I., Chin, W.C. \& Verdugo, P. (2003) ATP-independent luminal oscillations and release of $\mathrm{Ca}^{2+}$ and $\mathrm{H}^{+}$from mast cell secretory granules: implications for signal transduction. Biophys. J., 85, 963-970.

Rizzuto, R., Duchen, M.R. \& Pozzan, T. (2004) Flirting in little space: the $\mathrm{ER} /$ mitochondria $\mathrm{Ca}^{2+}$ liaison. Sci. STKE., doi:10.1126/stke.2152004re1

Scheenen, W.J., Wollheim, C.B., Pozzan, T. \& Fasolato, C. (1998) $\mathrm{Ca}^{2+}$ depletion from granules inhibits exocytosis. A study with insulin-secreting cells. J. Biol. Chem., 273, 19002-19008.

Shimomura, O. \& Johnson, F.H. (1973) Further data on the specificity of aequorin luminescence to calcium. Biochem. Biophys. Res. Commun., 53, 490-494.

Simon, J.P. \& Aunis, D. (1989) Biochemistry of the chromogranin A protein family. Biochem. J., 262, 1-13.

Ungermann, C., Wickner, W. \& Xu, Z. (1999) Vacuole acidification is required for trans-SNARE pairing, LMA1 release, and homotypic fusion. Proc. Natl Acad. Sci. USA, 96, 11194-11199.

Winkler, H. \& Westhead, E. (1980) The molecular organization of adrenal chromaffin granules. Neuroscience, 5, 1803-1823.

Wu, M.M., Grabe, M., Adams, S., Tsien, R.Y., Moore, H.P. \& Machen, T.E. (2001) Mechanisms of $\mathrm{pH}$ regulation in the regulated secretory pathway. J. Biol. Chem., 276, 33027-33035.

Yoo, S.H. \& Albanesi, J.P. (1991) High capacity, low affinity $\mathrm{Ca}^{2+}$ binding of chromogranin A. Relationship between the $\mathrm{pH}$-induced conformational change and $\mathrm{Ca}^{2+}$ binding property. J. Biol. Chem., 266, 7740-7745.

Zhou, Z. \& Neher, E. (1993) Mobile and immobile calcium buffers in bovine adrenal chromaffin cells. J. Physiol., 469, 245-273. 